\title{
Irony and (Dis)Obedience to Authority in Julian Barnes's The Noise of Time
}

Julian Barnes'ın Zamanın Gürültüsü Romanında İroni ve Otoriteye İtaat(sizlik)

\author{
Deniz Kırpıklı \\ Başkent University, Turkey
}

\begin{abstract}
Julian Barnes's novel, The Noise of Time, a biographical fiction about the Russian composer Dmitri Dmitriyevich Shostakovich, focuses on the most critical periods of the composer's career, during which he goes through the ordeal of being forced to conform to the ideology of the Soviet regime. Drawing on the composer's biography, Barnes provides the reader with a fictionalized view of how the composer survives the oppression by the use of irony, which is a much debated issue about his artistic persona. Power measures Shostakovich's integrity and pushes him to repudiate his artistic stance. The novel especially focuses on conveying the inner conflict of the composer and depicts him feeling shame because of his submission to Power. Under the threat of the authority, he holds on to irony which helps him overcome his fear and shame by implying his dissidence. The aim of this paper is to explore the role of irony in the relationship between art and power by discussing the compromises Shostakovich is forced to make. Also, by focusing on the inner struggle of the composer, this paper will investigate how the novel presents the ways through which the protagonist copes with the challenges in his life.
\end{abstract}

Keywords: Julian Barnes, Shostakovich, irony, power, music

Öz

Julian Barnes'ın Rus besteci Dmitri Dmitriyevich Shostakovich'in biyografisinden esinlendiği biyo-kurgu romanı Zamanın Gürültüsü, bestecinin kariyeri boyunca Sovyet rejim ideolojisine riayet etmeye zorlandığı en kritik dönemleri ele almaktadır. Barnes, bestecinin sanatçı kişiliğinin çok tartışmalı bir yönü olan ironi sayesinde bu baskı döneminde nasıl hayatta kaldığını kurgusal bir bakış açısıyla okuyucuya sunar. Otorite, Shostakovich'i sanatından taviz vermeye zorlar. Roman, özellikle bestecinin iç dünyasına odaklanır ve sanatından taviz vermekten duyduğu utancı tasvir eder. Shostakovich, otoritenin tehdidi altında, eserlerinde ve konuşmalarında kullandığı ironi ile muhalif yönünü ima ederek korku ve utanç hislerinin üstesinden gelmeye çalışır. Bu çalışma, bestecinin içinde bulunduğu zor durum üzerinden sanat ve otorite arasındaki ilişkide ironinin rolünü tartışmayı amaçlamaktadır. Ayrıca, romanda bestecinin kendi içinde verdiği mücadeleye odaklanılarak, onun hayattaki zorluklarla baş etme yollarının nasıl ele alındığı incelenecektir.

Anahtar Kelimeler: Julian Barnes, Shostakovich, ironi, otorite, müzik

CUJHSS, December 2020; 14/2: 263-276. DOI: 10.47777/cankujhss.848941

(C) Çankaya University ISSN 1309-6761 Printed in Ankara

Submitted: May 11, 2020; Accepted: Oct 1, 2020

ORCID\#: 0000-0002-0330-593X; d.kirpikli@gmail.com 
"Even if they cut off both my hands and I have to hold the pen in my teeth, I shall still go on writing music."1 -Shostakovich, Letter to Isaac Glikman, 1936

The Noise of Time (2016), which is a biographical fiction about the Russian composer Dmitri Dmitriyevich Shostakovich (1906-1975), deals with the most critical periods of the composer's career, during which he goes through the ordeal of being forced to conform to the ideology of the Soviet regime under Stalin and his successors. Drawing on the composer's biography, Barnes provides the reader with a fictionalized view of how the artist survives the oppression by use of irony, which is a much debated issue about his artistic persona. The narrative voice elaborates on how the protagonist tries to find the strength to go on creating his art. Power measures Shostakovich's integrity and pushes him to repudiate his artistic stance. Forced to comply with the requests of the state, he both condemns himself for his obedience and subverts his complicity by means of irony he uses in his public speech and his compositions. With a focus on the protagonist's reliance on irony and the ironic situations he finds himself in, this paper will explore the role of irony in the relationship between art and Power under the threat of the totalitarian regime by illustrating the compromises Shostakovich is compelled to make, and how the novel presents the ways through which the composer copes with the challenges in his life.

It is not surprising that Barnes, as a novelist who employs irony in his works, is interested in the biography of Shostakovich whose compositions are allegedly encoded with various forms of irony that express his covert dissidence against the Soviet system. Unlike Barnes's previous works, The Noise of Time does not involve self-reflexive postmodern elements. The novel is laden with irony, but it does not draw attention to the novel's status as a cultural artifice or express disenchantment with history; it is there to expose the repetition of oppression on art in different periods and the risks that are taken by the artist. It mocks the attempts of the totalitarian regime's attacks but the tragic aspect of the situation is foregrounded, because irony is not enough to fight the real anguish of life. The ironic perspective of the novel is reflected through the point of view of the protagonist as the focalizer of the narrative and his way of dealing with the threatening presence of the political oppression in his life. "All his life he had relied on irony" (Barnes 173), states the narrator; irony is in the protagonist's words, the incidents, and the repetition of the exact encounters that he tries to evade. His life itself is ironic as he is portrayed as a non-political composer but ends up being a Communist Party member as the Head of the Music Committee. Not only the incidents in his life but also his language and his personal way of dealing with difficult situations are rendered ironic, as the narrator reflects: " $[t]$ he natural progression of human life is from optimism to

\footnotetext{
${ }^{1}$ Shostakovich, Dmitri Dmitriyevich. Story of a Friendship: The Letters of Dmitry Shostakovich to Isaak Glikman, 1941-1975. Translated by Anthony Phillips, Cornell University Press, 2001, xix.
} 
pessimism; and a sense of irony helps temper pessimism, helps produce balance, harmony. But this was not an ideal world, and so irony grew in sudden and strange ways. Overnight, like a mushroom; disastrously, like a cancer" (86). Thus, the novel posits irony not as a strategy to lay bare the constructedness of grand narratives; rather irony serves as a coping strategy with the tragic aspects of life. At this point, the novel's dealing with the biography of Shostakovich is significant because he is portrayed to use irony in his music as a way of tolerating the predicaments of life and evading fascism in the novel. Thus, the use of irony in the novel runs parallel to the composer's real-life use of irony in different forms in his speech and music.

The novel is divided into three sections following the years 1936, 1948 and 1960 - titled "On the Landing", "On the Plane", and "In the Car" - each starting with a statement expressing that it was the worst time. Every time the protagonist thinks he is going through the worst, he encounters a worse experience with the authority and the novel draws attention to how ironical the situation is. It is as if all he goes through has taught him that "[a] soul could be destroyed in one of three ways: by what others did to you; by what others made you do to yourself; and by what you voluntarily chose to do to yourself" (166). Before looking into the way the novel depicts how Shostakovich continues to compose his music despite limitations, it would be wise to mention the after-note of the novel in which Barnes recommends his two main sources, Elizabeth Wilson's Shostakovich: A Life Remembered (1994) and Solomon Volkov's Testimony: The Memoirs of Shostakovich (1979) to the readers who are unsatisfied with his fictional account of the composer's life. Volkov's book, which claims to be reporting the composer's words, caused controversy over the intended instances of irony in his compositions. The book's authenticity and accuracy have been disputed by the authorities mainly because of its claim for Shostakovich's anti-Soviet agenda even in his works which were approved by the Party itself. ${ }^{2}$ Shostakovich was never overtly dissident but it is claimed that he reused some musical themes in his banned works (Gerstel 44). Unlike these biographical accounts of the composer, what Barnes focuses on conveying is Shostakovich's inner struggle with Power and how he copes with "the worst" of all times in the fictionalized interrogations in the novel. The narrative shifts back and forth through the protagonist's memories of good old days and the contemporary horrors he goes through. By combining assumed facts with fiction, the novel provides the reader with a deeper understanding of the protagonist's personality. In relation to the composer's biography, Barnes says in the Author's Note, "I have treated it as I would a private diary: as appearing to give the full truth, yet usually written at the same time of day, in the same prevailing mood, with the same prejudices and forgettings" (184). As such, the novel can be categorized as an example of biographical fiction, or biofiction, a term coined by French critic Alan Buisine in his "La Biographique" published in 1991. Biofiction refers to a genre influenced

\footnotetext{
2 There has been much debate about whether Shostakovich was a supporter of the regime or a political dissident. See lan McDonald, The New Shostakovic. Fourth Estate, 1990; Malcolm Hamrick Brown, A Shostakovich Casebook. Indiana University Press, 2004.
} 
by postmodernism and "cannot accurately signify or represent the biographical subject because the author's subjective orientation will always inflect the representation" (Lackey "Locating" 5). According to Broom, it is a "linguistic collage of two literary genres, biography and fiction, where both elements contribute their respective qualities to form a new, imaginative whole" (341). In his Biography and the Postmodern Historical Novel, Keener defines biofiction as a form that "applies 'novelistic' discourse to the representation of a historical life" (183). Similar to postmodern fiction's attempt to subvert what is assumed factual in history, biofiction tends to employ some "facts" from the biography of a well-known figure and reinvents some aspects of the past to emphasize an ignored aspect of it or to generate a different perspective towards it. As Lackey further explains,

[b]iographers seek to represent the life of the subject as accurately as possible, while authors of biofiction use the life of their subject in order to create their own vision of the world. This idea of using a life is of crucial importance, for it shifts the emphasis from biography's sacred art of accurate representation to the creative writer's sacred art of imaginative creation. (Biographical 10)

Thus, rather than an accurate life account of the biographical subject, the perception of the author is in the foreground. Barnes makes use of the composer's biographies, memoirs and documents, such as letters, and combines them with techniques like free indirect discourse and intertextuality to uncover and draw attention to possible current threats to art and freedom of speech. He also re-presents the composer's life to illustrate the relationship between art and Power. In so doing, Barnes both provides poetic justice for the composer and relates a highly crucial topic to a real-life story based on the actual life of the biographical subject. The novel makes its point clear in these lines:

The world had moved on, become more scientific, more practical, less under the sway of the superstitions. And tyrants had moved on as well. Perhaps conscience no longer had an evolutionary function, and so had been bred out. Penetrate beneath the modern tyrant's skin, go down layer after layer, and you will find the texture does not change, the granite encloses yet more granite; and there is no cave of conscience to be found. (164-165)

It is the way of the world that the novel urges the reader to question by illustrating the historical oppression Shostakovich went through. In the novel, Shostakovich is not portrayed as actually encoding some messages into his music but he is a lifelong dissident who is struggling to compose his music despite the threats of Power. Journalists and critics have tried to detect irony in Shostakovich's works but Barnes provides the protagonist's life, thoughts, and speech with irony. In the novel, his feelings and thoughts are revealed through interior monologues and a third person narrative. He is not allowed to make a choice; even though he does not approve the impositions of the government on his music, he pretends to be obedient by hiding his disobedience through irony. 
Barnes fictionalizes the three phases of the composer's life by making comments on irony which the composer lives on. In the first part of the novel, "On the Landing", Shostakovich's opera Lady Macbeth of Mtsensk is condemned by the official newspaper of the Communist Party, Pravda, as "Muddle Instead of Music" and as tickling "the perverted taste of the bourgeois with its fidgety, neurotic music" (Barnes 27). It is not signed but there is a strong possibility that Stalin himself wrote it. Shostakovich knows it is his death sentence. The novel demonstrates that the political control over music for propaganda conflicts with the creative spirit of art. The authority enforces censorship, and imposes party ideology on Shostakovich's creativity and pushes him to affirm the political agenda of the state and reflect it in his compositions. With regard to the relationship between culture and politics in Stalin's period, Sheila Fitzpatrick states that

[t]he party controlled culture and Stalin controlled the party. Involved in this interpretation were a number of specific propositions and assumptions, among which were (1) that the party assumed responsibility for guiding, and if necessary forcing, scholarship and the arts in certain directions, generally directions suggested by ideology; (2) that Stalin required an identifiable "party line" on all cultural questions, and thereby excluded the possibility of fundamental debate within the cultural professions; (3) that the Stalinist party rejected even the limited concepts of professional autonomy and academic and artistic freedom ... and by imposing total control deprived cultural institutions and professional organizations of all powers of initiative and negotiation; (4) that, as a consequence, there was a "we-they" relationship between the cultural intelligentsia and the party, with the party striving-usually successfully-to infuse its values into the intelligentsia. (212)

So, if you are not supporting the agenda of Power, you are not allowed to create art. The novel foregrounds the irrationality of cultural suppression through the arbitrariness of the incidents and repetition of the threats and accusations in different time periods. The protagonist has two options: to comply with the Party ideology and survive; or to get killed. He chooses the first option but adds an ironical touch to his creativity. Hayden White points out that throughout history, irony reflects its powerful "transideological" tool (38). Similarly, in her Irony's Edge, Linda Hutcheon contends that "it is because of its very foregrounding of the politics of human agency ... that irony has become an important strategy of oppositional rhetoric" (11-12). It is the function of irony that the protagonist makes use of throughout the novel.

Following the publication of the article in Pravda, the composers' union quickly condemns his opera, too, and many other editorials continue to attack his music for being pessimistic and immoral, without giving him an opportunity to defend himself. He is considered to be "Leftist, Petit-bourgeois, formalist" (Barnes 27) by the government. It was an era of terror; people get tortured, 
killed or disappear at the Big House; therefore, when he sees the editorial, he realizes that both his and his family's lives are in danger. He wonders,

[w]hy, ... had Power now turned its attention to music, and to him? Power had always been more interested in the word than the note: writers, not composers, had been proclaimed the engineers of human souls. Writers were condemned on page one of Pravda, composers on page three. Two pages apart. And yet it was not nothing: it could make the difference between death and life. (40)

The state started to search for a specific meaning among the notes of his compositions. It was a time when music was considered dangerous by Power as it was difficult to control. As Rothstein states, "recent totalitarian regimes have found all sorts of dangers in music we think of as totally harmless. ... Treason is heard in a musical dissonance, sedition in a harmonic modulation. The more tyrannical a regime, the more it seems to fear music" ("Musical"). In a similar vein, Mulcahy points out that under the totalitarian control of art in the late 1930s and early 40s,

realistic (that is, tonal) music is praised, atonal music is denounced; traditional aesthetic forms are held up for imitation, and the avantgarde is ridiculed; optimistic themes of socialist heroism are approved, while those that are overly explicit or critical are discouraged. Most important, the Party will impose a variety of restraints (ranging from sanctions to suppression) on artists who deviate from the official cultural canon. (70)

Any pessimistic note, according to the authorities, might cause a loss of public confidence about the future of the Soviet regime; therefore, Power made it clear that art should stimulate patriotism, optimism, and heroism in the public. Shostakovich's work is accused of being formalist, which means lack of optimistic melody and absence of a patriotic theme. In other words, he is considered to be too elitist and anti-socialist for the Soviet people. When he is announced to be "enemy of people" (Barnes 47) we see the composer anxiously waiting to be taken by the secret police in the first part of the novel. $\mathrm{He}$ is summoned to have a conversation with Power at the Big House and accused of complicity in a plot to kill Stalin. He is given two days by his interrogator Zakrevsky to confess everything and report about his friend and patron Tukhachevsky's misdeed. However, by an ironic twist of fate, it turns out that Zakrevsky himself is arrested for treason, and Tukhachevsky is later killed. Shostakovich is informed by the guards at the door: "Well, you can go home. You are not on the list. Zakrevsky isn't coming in today, so there's nobody to receive you" (50), so the composer's life is saved for now. Yet his works are forbidden to be performed, and Power forces him to serve the state by making his music simpler, more understandable, optimistic in tone, and ideologically appropriate for the people of the Soviet regime. Illustrating the corruption of the authorities holding all the power, the novel suggests the ways in which fascist authorities manipulate truth and shape its own reality to condemn anyone who does not comply with it. The protagonist thinks, "so this 
is what history has come to. All that striving and idealism and hope and progress and science and art and conscience, and it all ends like this, with a man standing by a lift, at his feet a small case containing cigarettes, underwear and tooth powder; standing there and waiting to be taken away" (41). It is an era when "facts were no longer facts, merely statements open to divergent interpretation" (Barnes 52). Therefore, he, in a way, embodies the position of art and progress in the face of totalitarian regimes that disappoint all the hopes for progress in the world. The narrative demonstrates the composer's life to be "a vast catalogue of little farces adding up to an immense tragedy" (172) through the perspective of the protagonist as the focalizer. In one of his concerts in Kharkov, as he remembers, "[h]is first Symphony had set all the neighbourhood dogs barking. The crowd laughed, the orchestra played louder, the dogs yapped all the more... Now, his music had set bigger dogs barking. History was repeating itself: the first time as farce, the second time as tragedy" (41). The predicaments he finds himself in are so random and ironic that the reaction of the government reminds him of the barking of dogs. His personality is crushed by shame because he has to compromise his principles and be loyal to Power for the sake of his and his family's survival. Beside the situational irony he experiences in his first encounter with the investigator, in his struggle with Power his only tool to defend his identity and art is irony which he uses in his music and public speeches to imply his actual but hidden defiance of tyranny.

Linda Hutcheon states that irony "can and does function tactically in the service of a wide range of political positions, legitimating or undercutting a wide variety of interests" (10). In the novel, the protagonist uses it as a strategy to resist political and cultural repression through covert meanings in his speech and works. It is an inherent strategy of irony as it "involves some sort of contrast between two levels of meaning, often coded 'apparent' and 'real'" (Jay 37). For instance, when Comrade Troshin, who is a sociologist, is informed that Stalin talked to Shostakovich on the phone, he says: "I am aware that you are a well-known composer, but who are you in comparison with our Great Leader?" (126) and Shostakovich uses verbal irony in his reply to him: "I am a worm in comparison with His Excellency. I am a worm" (126). Hiding his contempt for Stalin and mocking Troshin, Shostakovich reveals how he feels about his obedience at the same time. The narrative voice comments on irony as an ability to communicate two or more opposed meanings at once. Hutcheon explains this double-voicedness in irony by pointing out that irony

comes into being in the relations between meanings ... so that both the said and the unsaid together make up the third meaning. ... Irony functions as a set of dynamic and plural relations among the text or utterance (and its context), where meanings are slippery, multiple, and find their locations in the space between (and including) the said and the unsaid. (12-13)

In a similar vein, referring to the ambivalence of irony, Lang points out that "the double vision of irony reflects the uncertainty intrinsic to the 
determination of any intention" (578). In this sense, there has to be a mutual understanding between the speaker and the intended audience. As Goffman contends, "irony allows a speaker to address remarks to a recipient which the latter will understand quite well, ... know that he is known to understand; and yet neither participant will be able to hold the other responsible for what has been understood" (Goffman 515). Through irony, Shostakovich aims to disguise the real meaning in his music and speech and to make himself understood by his audience, who really wants to hear what he composes. In the novel, as the narrator states, "when truth-speaking became impossible ... it had to be disguised. ... And so, truth's disguise was irony. Because the tyrant's ear is rarely tuned to hear it" (85). He feels he has to secure his family's survival but he also wants to save the artistic merit of his music and retain his inner integrity. Irony is "implicated in questions of hierarchy and power" therefore, "instead of aiming at a direct expression of the speaker's attitude, it works through indirection" (Hutcheon 38). Thus, he has to be indirect in his nonconformity to the authority and struggle against the cultural repression. For ears untrained, it is not easy to detect ironic effect in music. In her study on the irony in Shostakovich's works, Gerstel sheds light on some parts of the composer's ironic twists:

The symphonies he wrote in his middle period ... are full of hidden messages, in-jokes, and allusions through which Shostakovich could phrase his frustrations, alienation, doubt, hope, and yearning, for an informed group of listeners. Certainly Shostakovich elicits special meanings from specific combinations of musical notes in a piece such as the Tenth, where his musical characterization of Stalin in the short and brutal second movement ... signals his disgust, blending emotions of furious anger with a technical refusal of melody. (44)

Accordingly, in some of his works, he exaggerates the length of optimistic themes to a ridiculous degree and while the authorities think they are listening to the notes of genuine feelings, actually the music is loaded with sarcasm to manifest his resistance. In doing so, Shostakovich makes use of another function of irony that is "trivializing the essential seriousness of art" (Hutcheon 46). When Shostakovich writes The Fifth Symphony, he composes the fourth movement starting with an upbeat and heroic character but ending in a slower tone like a funeral march to undercut the heroic quality (Thomas). He adds ambiguous parts which provide an optimistic atmosphere with the sound to evade the interpretation of the regime. It is regarded as an optimistic tragedy because Power just hears what they want to hear in his music: however, he considers what he is doing as "a clown's grin on a corpse" (Barnes 174). He is glad that "they missed the screeching irony of the final movement, that mockery of triumph. They hear only triumph itself, some loyal endorsement of Soviet music, Soviet musicology, of life under the sun of Stalin's constitution" (58). So, irony functions as an act of subversion of his apparent compliance with Power and also a means to preserve his dignity. In Barnes's words, irony, for the composer, becomes "a defence of the self and the soul" (173). Through 
his hidden disobedience which is the only source of relief for him, he is able to continue producing his art.

Shostakovich's second encounter with Power comes twelve years later, in 1948, when he is invited to represent the Soviet Union and give a propaganda speech, prepared by the state at Cultural and Scientific Conference for World Peace in New York. It was a time when The Fourth Symphony was banned due to its formalism but The Fifth Symphony got the approval from the state as "Shostakovich cut his aesthetics to meet the new Stalinist fashion" (Mulcahy 74). Only in twelve years, during which he continued to compose his most wellknown symphonies, "tyranny turned the world upside down" (Barnes 67) and he has come to a point where he compromises his principles. Especially the success of his The Seventh Symphony (Leningrad Symphony), which is about the siege of Leningrad by the Nazis, as a symbol of resistance to fascism, brought him international fame. However, as Volkov reports in Testimony, the invasion theme of the composition is in fact about "the Leningrad that Stalin destroyed and that Hitler merely finished off" (156). Power missed the irony and Shostakovich received prizes, memberships, and honorary degrees from several countries. Yet, his success ironically put him in a more dangerous position; the authority wanted him to be a puppet for the Party now. The Party condemned many composers for being formalists, such as Prokofiev and Khatchaturian, and Shostakovich is still in Zhdanov's blacklist for being a "formalist" for the authorities, so "the criticisms embodied in the 1936 Pravda editorial were still valid: Music - harmonious, graceful music - was required, not Muddle" (Barnes 77). He attempted to decline the invitation at first, as he is supposed to represent his country where his works have been banned; however, Stalin called to change his mind. So, he has an ironic conversation with Stalin who pretends not to be aware that Shostakovich's music is banned:

[Shostakovich:] The fact is, you see, that I am in a very difficult position. Over there, in America, my music is often played, whereas over here it is not played. They would ask me about it. So how am I to behave in such a situation?

[Stalin:] What do you mean, Dmitri Dmitrievich, that your music is not played?

[Shostakovich:] It is forbidden. As is the music of many of my colleagues in the Union of Composers.

[Stalin:] Forbidden? Forbidden by whom?

[Shostakovich:] By the State Commission for Repertoire. From the 14th of February last year. There is a long list of works which cannot be played. But the consequence, as you can imagine, Iosif Vissarionovich, is that concert managers are unwilling to programme any of my other compositions as well. And musicians are afraid to play them. So I am in effect blacklisted. As are my colleagues. (80-81)

That is how Zhdanov's decree is cancelled and Shostakovich attends the conference to praise the superiority of the Soviet vision for music. They demand a Communist consciousness in his music and speech that can be 
understood by the mass but "even conformity did not necessarily offer protection from imprisonment or execution" (Mulcahy 72). The novel reveals the ways in which Power seeks to enforce political control and impose its ideology making it universal through art but at the same time uncovers its irrationality. At the conference, Shostakovich becomes the target of the anticommunists who asks questions about his standing. Nicolas Nabokov, an exiled Russian composer working for the CIA, asks questions that force him to show his commitment to the Soviet regime and to praise the views of Soviet Communist Party leader Zhdanov, the man "who had persecuted him since 1936, who had banned him and derided him and threatened him, who had compared his music to that of a road drill and a mobile gas chamber" (Barnes 102). He answers all the questions by repeating a single sentence: "Yes, I personally subscribe to such views" (102). Also, he is forced to denounce his idol Stravinsky, who lives in exile in the United States, and his "moral barrenness" labelling him as a member of "a clique of reactionary modern musicians" (100). While he feels deeply humiliated for producing music that appears to conform to Soviet aesthetics, now Power pushes him one step further and degrades his public self by making him speak against his ideals. As the narrator puts it, "[h]e had betrayed Stravinsky, and in doing so, he had betrayed music. ... it had been the worst moment of his life" (110). There is no escape from the oppression and the embarrassment he feels; however, he knows that "the pleasures of irony had not yet deserted him" (158). Booth, in $A$ Rhetoric of Irony, states that irony is a "weapon of contempt" (43). Shostakovich reflects his contempt by delivering his speech at the conference in "a fast, uninflected gabble," (98) by creating the impression that these are not his own words and this is not him speaking. As Hutcheon contends, irony's defence mechanism works for "the politically repressed ... This is the function of irony that has specifically been called 'counter-discursive' in its ability to contest dominant habits of mind and expression" (49). In Shostakovich's case, his counter-discursive act is his exaggeration, the eagerness of his tone, the pace of his speech, in which irony lies. He wants the audience to realize that the text has not been written by him and that he was "a political imbecile" (Barnes 105). At least, he believes, he reminds the audience of "the one simple fact about the Soviet Union: that it was impossible to tell the truth here and live" (107).

Irony is also a form of personal resistance for Shostakovich. He has to write a letter to the representative of the state, after he agrees to attend the conference asking him to accept his "heartfelt gratitude for the conversation that took place yesterday. You supported me very much ... I cannot but be proud of the confidence that has been placed in me" (85). His way of thanking is a reflection of his inner conflict; seeming to comply with the requirements of the regime but at the same time implying his disobedience to retain his honour. He composes his music "for the ears that could hear" (92). In this sense, he expects the audience of his music to be aware of his true personality. Booth states that "[r]eading irony is in some ways like translating, like decoding, like deciphering, and like peering behind a mask" (33). The ironist and the reader 
must meet on a common ground to share the implicated meaning. Shostakovich hopes his messages to be decoded one day. The irony is not perceived by Power but, as he explains, the letter he writes, "would disappear into some file in some archive. It might stay there for decades, perhaps generations, perhaps 200,000,000,000 years; and then someone might read it, and wonder what exactly - if anything - he had meant by it" (85). Even if his opposition to Power is not perceived now, someday people will understand him and his dignity will be restored, he hopes.

Whenever an unfortunate event occurs in his life, irony helps him face the situation and overcome his fear and shame of the degradation of his artistic identity. Yet, irony fails to overcome the tragedy of life because whenever he thinks he is able to overcome the predicaments, things get worse. Sometimes he just wants to shout out to the world: "Do not trust what comes out of my mouth, trust only what goes into your ears" (168). Another instance of irony pervading his life is revealed in his thinking of himself as a courageous coward. To him, being a coward is more difficult than being courageous: he thinks that "to be a hero, you only had to be brave for a moment ... to be a coward was to embark on a career that lasted a lifetime. ... Being a coward required pertinacity, persistence, a refusal to change - which made it, in a way, a kind of courage" (158). He feels he is a coward for not standing his ground and resisting the authority but, at the same, surviving in this chaos in his own ways requires courage which he demonstrates through irony. Also, his considering suicide when he is already under the threat of execution contributes to the ironic tone of the narrative. In the final paragraph he hopes that

death would liberate his music: liberate it from his life. Time would pass, and though musicologists would continue their debates, his work would begin to stand for itself. History, as well as biography, would fade: perhaps one day Fascism and Communism would be merely words in textbooks. And then, if it still had value - if there were still ears to hear - his music would be ... just music" (179).

This is all he hopes for. He thinks his music will be what remains and be valued by people who can understand its merit. This is the hopeful note the novel presents by showing Shostakovich's artistic vision and ability to think of a better future. Also, although death would be an option to put him out of his misery, he knows that his suicide would be used by the Soviet authorities as an opportunity to destroy his legacy, musical achievements, and all his efforts so far; so, he chooses to live. He imagines,

[h] e was saying to the Union of Composers, to the cats who sharpened their claws on his soul, to Tikhon Nikolayevich Khrenikov, and to Stalin himself: Look what you have reduced me to, soon you will have my death on your hands and on your conscience. But he realized it was an empty threat, and Power's response hardly needed articulation. It would be this: Fine, go ahead, then we shall tell the world your story: The story of how ... how for decades you schemed to undermine Soviet music, how you corrupted younger composers, sought to restore 
capitalism in the USSR, and were a leading element in the musicologists' plot which will soon be disclosed to the world. (97)

At least he can still compose music and write his own story when he is alive. Even a small mistake would put his family and friends in jeopardy. He has to be alive to keep them safe. Throughout the novel, on the one hand, he is afraid of death and filled with self-hatred; on the other hand, he feels confident in his subversion of obedience to the state's demands on heroic and old-fashioned music. This capacity of subversion keeps him alive; despite all the horrors he goes through, he hopes his art will survive.

For Shostakovich, the final irony of his life is the fact that the Soviet authorities in fact kill him by "allowing him to live" (177). In this last part of the novel, which is set in 1960, Stalin is dead and Power is represented by Nikita Khrushchev. Shostakovich, recognized as the greatest Soviet composer, experiences his "final, and most ruinous Conversation with Power" (148), when Power compels him to become a member of the Communist Party and work as the chairman of the Russian Federation Union of Composers. He describes himself as a "hunchback," and "morally, spiritually" tortured (115):

'He could not live with himself.' It was just a phrase, but an exact one. Under the pressure of Power, the self-cracks and splits. The public coward lives with the private hero. Or vice versa. Or, more usually, the public coward lives with the private coward. But that was too simple: the idea of a man split into two by a dividing axe. Better: a man crushed into a hundred pieces of rubble, vainly trying to remember how they he - had once fitted together. (155)

He is no longer sure of irony's empowering and life-saving power because he is forced to sign the articles written by the state condemning his favourite writers and musicians. Again, it was the worst of all times: "[i]rony, he had come to realize, was as vulnerable to the accidents of life and time as any other sense. You woke up one morning and no longer knew if your tongue was in your cheek; and even if it was, whether that mattered any more, whether anyone noticed. ... And irony had its limits. For instance, you could not be an ironic torturer; or an ironic victim of torture" (174). After signing public denunciations of Solzhenitsyn and Sakharov, the critics of Stalin's regime, he feels he is betraying himself and "the good opinion others still held of him" (166). What makes him feel so exhausted is his silent attempts to resist the tyranny. He can never speak out against the regime, and especially being identified with the party policies leads him to feel distressed and embarrassed. Realizing that he can no longer manifest his non-conformity, he loses all his hope for the future. He cannot rely on irony, which is "disguise and communication" (Hutcheon 95), because having lost it all, it does not matter anymore whether anyone notices his irony: "you cannot sign letters while holding your nose or crossing your fingers behind your back, trusting that others will guess you do not mean it ... [you cannot] join the Party ironically" (Barnes 166; 175). His despair now that he has lost his tongue-in-cheek attitude is an implication that it was his ability to use irony that had helped him 
to survive by keeping his critical attitude so far. Since he is not capable of any counter-discursive act anymore, he remains as a tormented soul and thinks that he has lived too long and that is his fault. He thinks of the history of cultural oppression:

Lenin found music depressing.

Stalin thought he understood and appreciated music.

Khruschchev despised music.

Which is the worst for a composer? (115)

Power has always been there to prescribe forms of art and to make it a tool for its ideological agenda. This is a repetitive process, which makes the situation even more terrifying, but artistic creation has always found a way to emerge and reach its audience. The novel exemplifies this by fictionalizing the nature of Power and its manipulation of art by raising questions about the autonomy of art in today's world. Shostakovich is only one of the examples that have experienced cultural suppression. His musical achievements have survived despite the constant threat of tyranny and he managed to produce his art reflecting in his works "the true nature of [his] public masquerade" (105).

Combining biographical narrative with historical realities in a fictionalized form provides a space for the novel to give voice to what is suppressed. In one of his classes, Shostakovich is forced to test his students on Soviet ideology, and ponders on Lenin's statement "Art belongs to the people" (91) displayed on a banner at the conservatoire. Unlike the statement, Shostakovich thinks that "[a]rt belongs to everybody and nobody. Art belongs to all time and no time. Art belongs to those who create it and those who savour it. ... Art is the whisper of history, heard above the noise of time" (91). As imagined by Barnes, in the end it is music Shostakovich is able to "put up against the noise of time" (91). He clung to his artistic vision despite the political pressure throughout his career. As a man who is ashamed of his duplicity in his entire life, he cherished his music and "as long [he] could rely on irony, [he][was]be able to survive" (174). Irony has become more of a tool for surviving his internal thoughts and self-criticism than surviving the terror in the end.

\section{Works Cited}

Barnes, Julian. The Noise of Time. Jonathan Cape, 2016.

Booth, Wayne C. A Rhetoric of Irony. The University of Chicago Press, 1974.

Broom, Martha. “Constructing an Identity Of 'Relation' In Régine Robin's 'L'immense Fatigue Des Pierres."' Romance Notes, vol. 48, no. 3, 2008, pp. 335-343.

Fitzpatrick, Sheila. "Culture and Politics under Stalin: A Reappraisal." Slavic Review, vol. 35, no. 2, 1976, pp. 211-231.

Gerstel, Jennifer. "Irony, Deception, and Political Culture in the Works of Dmitri Shostakovich." Mosaic: An Interdisciplinary Critical Journal, vol. 32, no. 4, 1999, pp. 35-51.

Goffman, Erving. Frame Analysis: An Essay on the Organization of Experience. Harvard University Press, 1974.

Hutcheon, Linda. Irony's Edge: The Theory and Politics of Irony. Routledge, 1994. 
Jay, Martin. "Intention and Irony: The Missed Encounter Between Hayden White and Quentin Skinner." History and Theory, vol. 52, no. 1, 2013, pp. 32-48.

Keener, John F. Biography and the Postmodern Historical Novel. Mellen, 2001.

Lackey, Michael. Biographical Fiction: A Reader. Bloomsbury Academic, 2017.

---. "Locating and Defining the Bio in Biofiction." Biography Studies, vol. 31, no. 1, 2016, pp. 3-10.

Lang, Berel. "The Limits of Irony." New Literary History, vol. 27, no. 3, 1996, pp. 571588.

Mulcahy, Kevin V. "Official Culture and Cultural Repression: The Case of Dmitri Shostakovich." Journal of Aesthetic Education, vol. 18, no. 3, 1984, pp. 69-83.

Rothstein, Edward. "Musical Freedom and Why Dictators Fear It." The New York Times, 23 Aug. 1981. https://www.nytimes.com/1981/08/23/arts/musicalfreedom-and-why-dictators-fear-it.html.

Thomas, Michael Tilson. "Shostakovich's Symphony No. 5." Keeping Score, 2009. https://www.pbs.org/keepingscore/shostakovich-symphony-5.html

Volkov, Solomon. Testimony: The Memoirs of Dimitri Shostakovich. Limelight Editions, 1984. 